\title{
Pseudomonas tuomuerensis sp. nov., isolated from a bird's nest
}

\author{
Yu-Hua Xin, ${ }^{1}$ De-Chao Zhang, ${ }^{1}$ Hong-Can Liu, ${ }^{1}$ Hui-Ling Zhou ${ }^{1}$ \\ and Yu-Guang Zhou ${ }^{1,2}$ \\ ${ }^{1}$ China General Microbiological Culture Collection Center, Institute of Microbiology, Chinese \\ Academy of Sciences, Beijing 100101, PR China \\ ${ }^{2}$ State Key Laboratory of Microbial Resources, Institute of Microbiology, Chinese Academy of \\ Sciences, Beijing 100101, PR China
}

\begin{abstract}
Strain $78-123^{\top}$ was isolated from a sample of a bird's nest situated on the bank of Qiongtailan River in the region of Tuomuer Peak of Tianshan Mountain in the Xin-jiang Uygur Autonomous Region in north-western China. Phylogenetic analysis based on 16S rRNA gene sequence similarity showed that strain $78-123^{\top}$ was related to members of the genus Pseudomonas. $16 \mathrm{~S}$ rRNA gene sequence similarity between strain $78-123^{\top}$ and Pseudomonas mendocina ATCC $25411^{\top}$, Pseudomonas pseudoalcaligenes JCM 5968 ${ }^{\top}$ and Pseudomonas alcaliphila AL15-21 ${ }^{\top}$

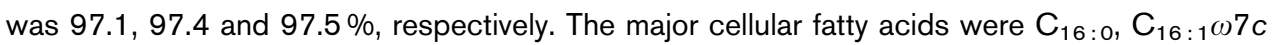
and/or iso- $\mathrm{C}_{15: 0} 2-\mathrm{OH}, \mathrm{C}_{18: 1} \omega 7 \mathrm{c}$ and $\mathrm{C}_{12: 0}$. The $\mathrm{G}+\mathrm{C}$ content was $60.4 \mathrm{~mol} \%$. On the basis of the phenotypic characteristics, phylogenetic analysis and DNA-DNA relatedness data, the novel species Pseudomonas tuomuerensis sp. nov. is proposed, with the type strain $78-123^{\top}$ $\left(=\right.$ CGMCC $\left.1.1365^{\top}=\mathrm{JCM} 14085^{\top}\right)$.
\end{abstract}

The pseudomonads are widespread in nature and are found in habitats such as soil, plants, animals and water (Palleroni, 1984). They play important roles in the environment, food safety and disease (Stanier et al., 1966; Palleroni, 1984; Las Heras et al., 1999). Anzai et al. (2000) analysed the phylogenetic relationships of $16 \mathrm{~S}$ rRNA gene sequences of 128 Pseudomonas species with and without validly published names, of which 57 were recognized as members of Pseudomonas sensu stricto. The phylogenetic analysis divided these 57 species into seven groups. This result conformed well with the rRNA-DNA hybridization study of Palleroni et al. (1973). The genus Pseudomonas sensu stricto now includes more than 100 species with validly published names (Tvrzová et al., 2006; Prakash et al., 2007).

During an investigation of the bacterial community in the region of Tuomuer Peak of Tianshan Mountain, in the Xin-jiang Uygur Autonomous Region in north-western China, a Pseudomonas-like bacterium strain $78-123^{\mathrm{T}}$ was isolated from a sample of a bird's nest situated on the bank of the Qiongtailan River at an elevation of $2400 \mathrm{~m}$. The strain was investigated by using a polyphasic taxonomic

The GenBank/EMBL/DDBJ accession number for the 16S rRNA gene sequence of strain $78-123^{\top}$ is DQ868767.

A comparison of cellular fatty acid profiles of strain $78-123^{\top}$ and related strains, results of 2D TLC of polar lipids of strain $78-123^{\top}$ and related strains and electron micrographs of cells of strain $78-123^{\top}$ are available as supplementary material with the online version of this paper. approach. Based on the molecular and phenotypic data, including phylogenetic analysis, DNA-DNA hybridization, biochemical and physiological tests, fatty acid analysis, cellular polar lipid analysis and ubiquinone system analysis, we propose a novel species of the genus Pseudomonas.

Strain $78-123^{\mathrm{T}}$ was isolated using nutrient agar medium at $30{ }^{\circ} \mathrm{C}$. It was obtained in pure culture after three successive transfers to fresh agar medium and stored at $-80{ }^{\circ} \mathrm{C}$ in $30 \%(\mathrm{v} / \mathrm{v})$ glycerol. Pseudomonas mendocina CGMCC $1.1804^{\mathrm{T}}$, Pseudomonas pseudoalcaligenes CGMCC $1.1806^{\mathrm{T}}$ and Pseudomonas alcaliphila JCM $10630^{\mathrm{T}}$, obtained from the CGMCC and JCM, were used as reference strains for phenotypic tests and other analyses. These strains were routinely incubated at $30{ }^{\circ} \mathrm{C}$ on nutrient agar except when mentioned otherwise.

Genomic DNA was extracted according to the method of Marmur (1961). PCR amplification of the 16S rRNA gene used primers 27f (5'-AGAGTTTGATCCTGGCTCAG-3') and $1492 \mathrm{r} \quad\left(5^{\prime}\right.$-TACGGCTACCTTGTTACGACTT- $\left.3^{\prime}\right)$ (Lane, 1991). The PCR products were sequenced on an ABI PRISM 3730 XL DNA Sequencer using the ABI PRISM BigDye v. 3.1 Terminator Chemistry kit (PE Applied Biosystems). Sequences related to the $16 \mathrm{~S}$ rRNA gene sequence of strain $78-123^{\mathrm{T}}$ were retrieved from the GenBank database. Sequences were aligned using the CLUSTAL W program (Thompson et al., 1994). Phylogenetic trees were reconstructed according to the neighbour-joining (Saitou \& Nei, 1987), maximum-likelihood 
(Felsenstein, 1981) and maximum-parsimony (Fitch, 1971) algorithms using the software package MEGA (version 3.1) (Kumar et al., 2004). The same results were obtained from these three methods. Parsimony analysis was achieved according to Kimura's two-parameter model for the neighbour-joining method. The tree topology and distances were determined with bootstrap analysis based on 1000 resamplings. The analysis of almost-complete $16 \mathrm{~S}$ rRNA gene sequences (Fig. 1) showed that strain $78-123^{\mathrm{T}}$ belonged to the Pseudomonas aeruginosa group (Anzai et al., 2000 ). The $16 \mathrm{~S}$ rRNA gene sequence similarity of strain 78$123^{\mathrm{T}}$ with $P$. mendocina ATCC $25411^{\mathrm{T}}, P$. pseudoalcaligenes JCM $5968^{\mathrm{T}}$ and P. alcaliphila AL15-21 ${ }^{\mathrm{T}}$ was $97.1,97.4$ and $97.5 \%$, respectively.

The $\mathrm{G}+\mathrm{C}$ content of the DNA was determined by the thermal denaturation method (Marmur \& Doty, 1962) with Escherichia coli K-12 as the reference. Levels of DNADNA hybridization were determined from the initial DNA-DNA liquid reassociation rate as described by De Ley et al. (1970). Tests were performed on a model Lambda

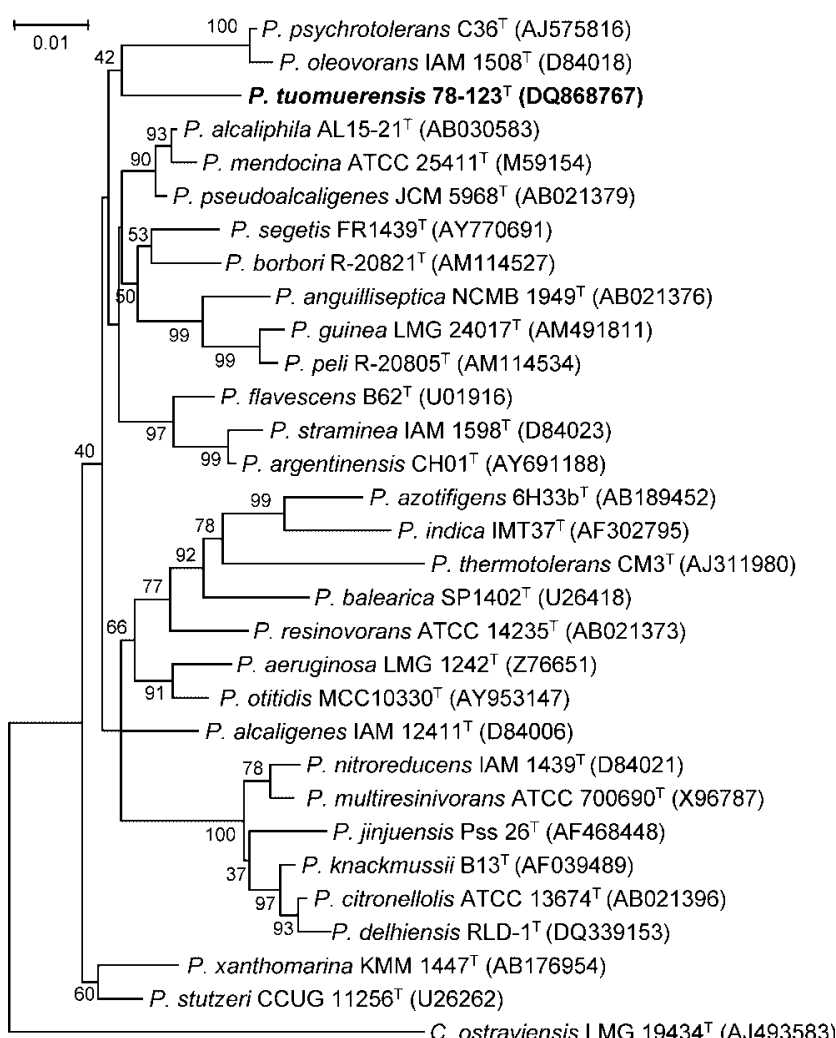

Fig. 1. Phylogenetic tree of strain $78-123^{\top}$ and related taxa based on $16 \mathrm{~S}$ rRNA gene sequence comparisons using the neighbourjoining method (Saitou \& Nei, 1987). The sequence of Cellvibrio ostraviensis LMG $19434^{\top}$ was used as an outgroup. GenBank accession numbers are given in parentheses. Numbers represent percentage confidence levels from 1000 replicate bootstrap sampling. Bar, 0.01 nucleotide substitution per 100 positions.
$35 \mathrm{UV} / \mathrm{Vis}$ spectrometer equipped with a temperature program controller (Perkin-Elmer). The DNA G+C content of strain $78-123^{\mathrm{T}}$ was $60.4 \mathrm{~mol} \%$. DNA-DNA relatedness values of strain $78-123^{\mathrm{T}}$ with the type strains $P$. mendocina CGMCC $1.1804^{\mathrm{T}}$, P. pseudoalcaligenes CGMCC $1.1806^{\mathrm{T}}$ and P. alcaliphila JCM $10630^{\mathrm{T}}$ were $27.8,31.1$ and $26.5 \%$, respectively. The results of DNA-DNA hybridization, which were based on three independent determinations, indicated that strain $78-123^{\mathrm{T}}$ was a member of a different species from $P$. mendocina CGMCC $1.1804^{\mathrm{T}}, P$. pseudoalcaligenes CGMCC $1.1806^{\mathrm{T}}$ and P. alcaliphila JCM $10630^{\mathrm{T}}$.

In order to observe their morphology, cells of strain 78$123^{\mathrm{T}}$ were stained with $1 \%(\mathrm{w} / \mathrm{v})$ phosphotungstic acid and observed with a Hitachi H-600 transmission electron microscope. Colony morphology was observed on nutrient agar after incubation at $30{ }^{\circ} \mathrm{C}$. In order to test the requirement for $\mathrm{O}_{2}$, the strain was incubated in $0.2 \%$ nutrient agar. Growth with carbon sources was tested by using Gram-negative MicroPlates (Biolog) according to the manufacturer's instructions. Data were analysed using the software package provided by Biolog. The production of acid from carbohydrates was determined using the method of Hugh \& Leifson (1953). Methyl red and VogesProskauer tests, nitrate reduction, $\mathrm{H}_{2} \mathrm{~S}$ production, starch hydrolysis, gelatin liquefaction, aesculin and casein hydrolysis and urease, lipase (Tweens 20, 40 and 80), arginine dihydrolase and phenylalanine deaminase activities were tested according to the methods of Smibert \& Krieg (1981). For observing fluorescent pigments, King B medium (King et al., 1954) was used. The morphological, cultural, physiological and biochemical characteristics of strain 78$123^{\mathrm{T}}$ are given in the species description.

Respiratory quinones were extracted and purified according to the method of Collins (1985) and were analysed by HPLC (Wu et al., 1989), with a previously characterized mixture of various ubiquinones ( $\mathrm{Hu}$ et al., 2001) as a reference. The predominant ubiquinone was Q-9, which was in agreement with the result of Stolz et al. (2007).

Cellular fatty acids were determined for strain $78-123^{\mathrm{T}}$ after growth on nutrient agar at $30{ }^{\circ} \mathrm{C}$ for $24 \mathrm{~h}$, and were extracted, methylated and analysed using the standard MIDI System (Sasser, 1990). P. mendocina CGMCC $1.1804^{\mathrm{T}}, P$. pseudoalcaligenes CGMCC $1.1806^{\mathrm{T}}$ and $P$. alcaliphila JCM $10630^{\mathrm{T}}$ were grown under the same conditions before fatty acid analysis. The four strains had similar fatty acid profiles (Supplementary Table S1, available in IJSEM Online). Their major cellular fatty acids were $\mathrm{C}_{16: 0}, \mathrm{C}_{16: 1} \omega 7 c$ and/or iso- $\mathrm{C}_{15: 0} 2-\mathrm{OH}, \mathrm{C}_{18: 1} \omega 7 c$ and $\mathrm{C}_{12: 0}$. The main differences between strain $78-123^{\mathrm{T}}$ and its closest relatives were $\mathrm{C}_{15: 1} \omega 6 c, \mathrm{C}_{9: 0} 3-\mathrm{OH}$ and three isobranched fatty acids (iso- $\mathrm{C}_{13: 0}$, iso- $\mathrm{C}_{16: 0}$ and iso- $\mathrm{C}_{17: 0}$ ), which were not detected in strain $78-123^{\mathrm{T}}$ but were detected in P. mendocina CGMCC $1.1804^{\mathrm{T}}, P$. pseudoalcaligenes CGMCC $1.1806^{\mathrm{T}}$ and P. alcaliphila JCM $10630^{\mathrm{T}}$, and three anteiso-branched fatty acids (anteiso- $\mathrm{C}_{14: 0}$, 
anteiso- $\mathrm{C}_{15: 0}$ and anteiso- $\left.\mathrm{C}_{17: 0}\right)$ that were detected in strain $78-123^{\mathrm{T}}$ but were not detected in $P$. mendocina CGMCC $1.1804^{\mathrm{T}}, P$. pseudoalcaligenes CGMCC $1.1806^{\mathrm{T}}$ or P. alcaliphila JCM $10630^{\mathrm{T}}$.
Cellular polar lipids were extracted and analysed on silicagel plates (Kieselgel 60F; Merck) by two-dimensional TLC (Kates, 1986). Strain $78-123^{\mathrm{T}}$, P. mendocina CGMCC $1.1804^{\mathrm{T}}, P$. pseudoalcaligenes CGMCC $1.1806^{\mathrm{T}}$ and $P$.

Table 1. Phenotypic characteristics that differentiate strain $78-123^{\top}$ from the type strains of closely related Pseudomonas species

Strains: 1, Pseudomonas tuomuerensis sp. nov. $78-123^{\mathrm{T}} ; 2$, P. mendocina CGMCC $1.1804^{\mathrm{T}}$; 3, P. pseudoalcaligenes CGMCC $1.1806^{\mathrm{T}}$; 4 , P. alcaliphila JCM $10630^{\mathrm{T}}$. Data were obtained in this study unless indicated. The other characteristics of $P$. mendocina, $P$. pseudoalcaligenes and $P$. alcaliphila determined in this study were congruent with those reported by Palleroni $(1984,2005)$ and Yumoto et al. (2001). All the strains were positive for oxidase and catalase activities and for reduction of nitrate to nitrite. None of the strains hydrolysed starch. All four strains were positive for utilization of Tween 40, D- and L-lactic acid, acetic acid, succinic acid, pyruvic acid methyl ester and succinic acid monomethyl ester, and all four strains were negative for utilization of $\alpha$-cyclodextrin, dextrin, $N$-acetyl-D-galactosamine, $N$-acetyl-D-glucosamine, adonitol, D-arabitol, cellobiose, i-erythritol, L-fucose, D-galactose, gentiobiose, myo-inositol, $\alpha$-D-lactose, lactulose, maltose, D-mannose, melibiose, methyl $\beta$-D-glucoside, D-psicose, raffinose, L-rhamnose, D-sorbitol, sucrose, trehalose, turanose, xylitol, D-galactonic acid lactone, D-glucosaminic acid, $p$-hydroxyphenylacetic acid, $\alpha$-ketovaleric acid, sebacic acid, glucuronamide, L-alanyl glycine, glycyl L-aspartic acid, glycyl L-glutamic acid, hydroxy-L-proline, L-ornithine, Lphenylalanine, D-serine, inosine, uridine, thymidine, phenylethylamine, 2,3-butanediol, glycerol, DL- $\alpha$-glycerol phosphate, $\alpha$-D-glucose 1-phosphate and D-glucose 6-phosphate.

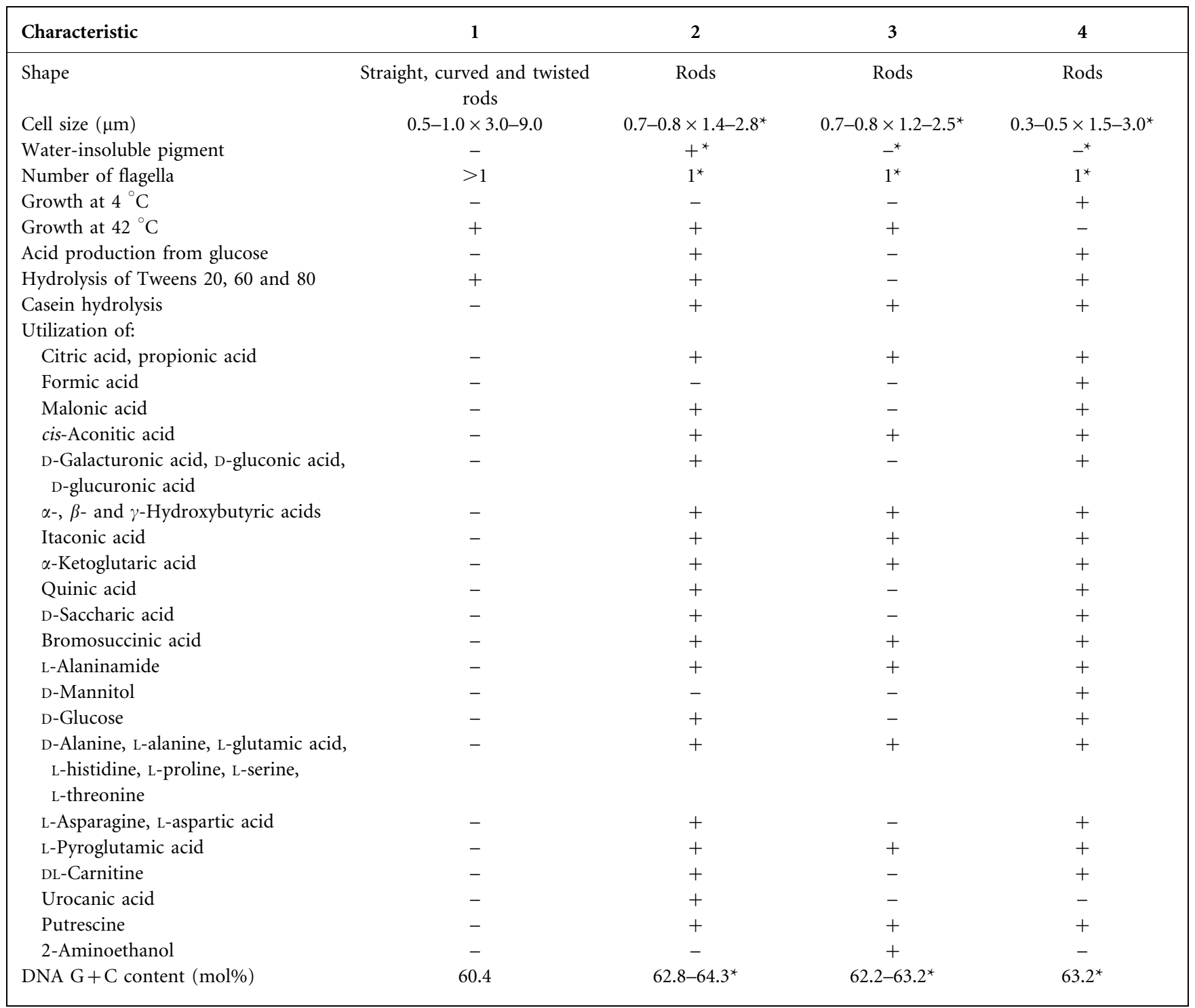

${ }^{\star}$ Taken from Palleroni $(1984,2005)$ and Yumoto et al. (2001). Ranges of DNA G+C content are results for multiple strains. 
alcaliphila JCM $10630^{\mathrm{T}}$ showed similar polar lipid profiles (Supplementary Fig. S1). The major polar lipids were phosphatidylethanolamine, diphosphatidylglycerol, phosphatidylglycerol and phosphatidylcholine. These major polar lipids are the same as those reported for two other members of the genus, Pseudomonas psychrotolerans DSM $15758^{\mathrm{T}}$ and P. oleovorans DSM $1045^{\mathrm{T}}$ (Hauser et al., 2004). However, Pseudomonas knackmussii DSM $6978^{\mathrm{T}}, P$. citronellolis DSM $50332^{\mathrm{T}}$, P. nitroreducens DSM $14399^{\mathrm{T}}$ and $P$. jinjuensis DSM $16612^{\mathrm{T}}$ lacked phosphatidylcholine. These results support the suggestion that polar lipid profiles may be useful for characterizing subgroups within the genus Pseudomonas sensu stricto (Stolz et al. 2007). Trace amounts of some unknown lipids could differentiate strain $78-123^{\mathrm{T}}$ from its closest relatives $P$. mendocina CGMCC $1.1804^{\mathrm{T}}$, P. pseudoalcaligenes CGMCC $1.1806^{\mathrm{T}}$ and P. alcaliphila JCM $10630^{\mathrm{T}}$.

Strain $78-123^{\mathrm{T}}$ was distinguishable from recognized Pseudomonas species by several phenotypic characteristics (Table 1). On the basis of the phenotypic, genotypic and phylogenetic data, we conclude that strain $78-123^{\mathrm{T}}$ represents a novel species of the genus Pseudomonas, for which the name Pseudomonas tuomuerensis sp. nov. is proposed.

\section{Description of Pseudomonas tuomuerensis sp. nov.}

Pseudomonas tuomuerensis (tuo.mu.er.en'sis. N.L. fem. adj. tuomuerensis pertaining to the region of Tuomuer Peak of Tianshan Mountain, where the type strain was isolated).

Cells are Gram-negative, aerobic and motile with polar multitrichous flagella, sometimes twisted into a fascicle or bundle, in a $24 \mathrm{~h}$ culture (Supplementary Fig. S2). Colonies are white, convex, round, translucent, waved on the edge and 3.0-6.0 $\mathrm{mm}$ in diameter after $72 \mathrm{~h}$ incubation on nutrient agar plates. Does not produce fluorescent pigments. No acid is produced from glucose. Growth occurs at $15-42{ }^{\circ} \mathrm{C}$; no growth at 4 or $45{ }^{\circ} \mathrm{C}$. Grows on medium containing $0-6.5 \%(\mathrm{w} / \mathrm{v}) \mathrm{NaCl}$. Tests for oxidase, catalase, urease, arginine dihydrolase and phenylalanine deaminase activities are positive. Hydrolyses Tweens 20, 60 and 80 but not gelatin, starch or casein. Negative for production of hydrogen sulfide, poly- $\beta$-hydroxybutyric acid and indole; positive for nitrate reduction. Methyl red and Voges-Proskauer tests are negative. Uses the following as carbon sources: Tweens 40 and 80 , L-arabinose, pyruvic acid methyl ester, succinic acid monomethyl ester, acetic acid, D- and L-lactic acid and succinic acid. Does not utilize the following as carbon sources: $\alpha$-cyclodextrin, dextrin, glycogen, $N$-acetyl-D-galactosamine, $N$-acetyl-D-glucosamine, adonitol, D-arabitol, cellobiose, i-erythritol, Dfructose, L-fucose, D-galactose, gentiobiose, $\alpha$-D-glucose, myo-inositol, $\alpha$-D-lactose, lactulose, maltose, D-mannitol, $\mathrm{D}$-mannose, melibiose, methyl $\beta$-D-glucoside, D-psicose, raffinose, L-rhamnose, D-sorbitol, sucrose, trehalose, turanose, xylitol, cis-aconitic acid, citric acid, formic acid, Dgalactonic acid lactone, D-galacturonic acid, D-gluconic acid, D-glucosaminic acid, D-glucuronic acid, $\alpha$-, $\beta$ - and $\gamma$ hydroxybutyric acids, $p$-hydroxyphenylacetic acid, itaconic acid, $\alpha$-ketobutyric acid, $\alpha$-ketoglutaric acid, $\alpha$-ketovaleric acid, malonic acid, propionic acid, quinic acid, D-saccharic acid, sebacic acid, bromosuccinic acid, succinamic acid, glucuronamide, L-alaninamide, D- or L-alanine, L-alanyl glycine, L-asparagine, L-aspartic acid, L-glutamic acid, glycyl L-aspartic acid, glycyl L-glutamic acid, L-histidine, hydroxy-L-proline, L-leucine, L-ornithine, L-phenylalanine, L-proline, L-pyroglutamic acid, D- or L-serine, L-threonine, DL-carnitine, $\gamma$-aminobutyric acid, urocanic acid, inosine, uridine, thymidine, phenylethylamine, putrescine, 2-aminoethanol, 2,3-butanediol, glycerol, DL- $\alpha$-glycerol phosphate, $\alpha$-D-glucose 1-phosphate or D-glucose 6-phosphate. Does not form acids from mannose, ribose, glycerol, mannitol, inulin, sorbitol, galactose, cellobiose, rhamnose, salicin, glucose, arabinose, xylose, melibiose, adonitol, fructose, lactose, inositol, raffinose, melezitose, methyl $\alpha$ D-glucoside, sucrose, maltose, sorbose, trehalose, dulcitol, i-erythritol or amygdalin. The major cellular fatty acids are $\mathrm{C}_{16: 0}, \mathrm{C}_{16: 1} \omega 7 c$ and/or iso- $\mathrm{C}_{15: 0} \quad 2-\mathrm{OH}, \mathrm{C}_{18: 1} \omega 7 c$ and $\mathrm{C}_{12: 0}$. The predominant ubiquinone is Q-9. The major polar lipids are phosphatidylethanolamine, diphosphatidylglycerol, phosphatidylglycerol and phosphatidylcholine. The $\mathrm{G}+\mathrm{C}$ content of the type strain is $60.4 \mathrm{~mol} \%$.

The type strain, $78-123^{\mathrm{T}} \quad\left(=\mathrm{CGMCC} \quad 1.1365^{\mathrm{T}}=\mathrm{JCM}\right.$ $14085^{\mathrm{T}}$ ), was isolated from a sample of a bird's nest situated on the bank of Qiongtailan River in the region of Tuomuer Peak of Tianshan Mountain in the Xin-jiang Uygur Autonomous Region in north-western China.

\section{References}

Anzai, Y., Kim, H., Park, J.-Y., Wakabayashi, H. \& Oyaizu, H. (2000). Phylogenetic affiliation of the pseudomonads based on 16S rRNA sequence. Int J Syst Evol Microbiol 50, 1563-1589.

Collins, M. D. (1985). Isoprenoid quinone analysis in classification and identification. In Chemical Methods in Bacterial Systematics, pp. 267-287. Edited by M. Goodfellow \& D. E. Minnikin. London: Academic Press.

De Ley, J., Cattoir, H. \& Reynaerts, A. (1970). The quantitative measurement of DNA hybridization from renaturation rates. Eur $J$ Biochem 12, 133-142.

Felsenstein, J. (1981). Evolutionary trees from DNA sequences: a maximum likelihood approach. J Mol Evol 17, 368-376.

Fitch, W. M. (1971). Toward defining the course of evolution: minimum change for a specific tree topology. Syst Zool 20, 406-416.

Hauser, E., Kämpfer, P. \& Busse, H.-J. (2004). Pseudomonas psychrotolerans sp. nov. Int J Syst Evol Microbiol 54, 1633-1637.

Hu, H. Y., Lim, B. R., Goto, N. \& Fujie, K. (2001). Analytical precision and repeatability of respiratory quinones for quantitative study of microbial community structure in environmental samples. J Microbiol Methods 47, 17-24.

Hugh, R. \& Leifson, E. (1953). The taxonomic significance of fermentative versus oxidative metabolism of carbohydrates by various Gram-negative bacteria. J Bacteriol 66, 24-26.

Kates, M. (1986). Techniques of Lipidology, 2nd edn. Amsterdam: Elsevier. 
King, E. O., Ward, M. K. \& Raney, D. E. (1954). Two simple media for the demonstration of pyocyanin and fluorescin. J Lab Clin Med 44, 301-307.

Kumar, S., Tamura, K. \& Nei, M. (2004). MEGA 3: integrated software for molecular evolutionary genetics analysis and sequence alignment. Brief Bioinform 5, 150-163.

Lane, D. J. (1991). 16S/23S rRNA sequencing. In Nucleic Acid Techniques in Bacterial Systematics, pp. 115-175. Edited by E. Stackebrandt \& M. Goodfellow. London: Wiley.

Las Heras, A., Domínguez, L., López, I. \& Fernández-Garayzábal, J. F. (1999). Outbreak of acute ovine mastitis associated with Pseudomonas aeruginosa infection. Vet Rec 145, 111-112.

Marmur, J. (1961). A procedure for the isolation of deoxyribonucleic acid from microorganisms. J Mol Biol 3, 208-218.

Marmur, J. \& Doty, P. (1962). Determination of the base composition of deoxyribonucleic acid from its thermal denaturation temperature. $J$ Mol Biol 5, 109-118.

Palleroni, N. J. (1984). Genus I. Pseudomonas Migula 1894, $237^{\mathrm{AL}}$ (nom. cons. Opin. 5, Jud. Comm. 1952, 237). In Bergey's Manual of Systematic Bacteriology, vol. 1, pp. 141-199. Edited by N. R. Krieg \& J. G. Holt. Baltimore: Williams \& Wilkins.

Palleroni, N. J. (2005). Genus I. Pseudomonas Migula 1894, 237 ${ }^{\mathrm{AL}}$ (nom. cons. Opin. 5 of the Jud. Comm. 1952, 121). In Bergey's Manual of Systematic Bacteriology, 2nd edn, vol. 2, part B, pp. 323-379. Edited by D. J. Brenner, N. R. Krieg, J. T. Staley \& G. M. Garrity. New York: Springer.

Palleroni, N. J., Kunisawa, R., Contopoulou, R. \& Doudoroff, M. (1973). Nucleic acid homologies in the genus Pseudomonas. Int J Syst Bacteriol 23, 333-339.

Prakash, O., Kumari, K. \& Lal, R. (2007). Pseudomonas delhiensis sp. nov., from a fly ash dumping site of a thermal power plant. Int J Syst Evol Microbiol 57, 527-531.
Saitou, N. \& Nei, M. (1987). The neighbor-joining method: a new method for reconstructing phylogenetic trees. Mol Biol Evol 4, 406425.

Sasser, M. (1990). Identification of bacteria by gas chromatography of cellular fatty acids. Technical Note 101. Newark, DE: MIDI.

Smibert, R. M. \& Krieg, N. R. (1981). General characterization. In Manual of Methods for General Bacteriology, pp. 409-443. Edited by P. Gerhardt, R. G. E. Murray, R. N. Costilow, E. W. Nester, W. A. Wood, N. R. Krieg \& G. B. Phillips. Washington, DC: American Society for Microbiology.

Stanier, R. Y., Palleroni, N. J. \& Doudoroff, M. (1966). The aerobic pseudomonads: a taxonomic study. J Gen Microbiol 43, 159-271.

Stolz, A., Busse, H.-J. \& Kämpfer, P. (2007). Pseudomonas knackmussii sp. nov. Int J Syst Evol Microbiol 57, 572-576.

Thompson, J. D., Higgins, D. G. \& Gibson, T. J. (1994). CLUSTAL W: improving the sensitivity of progressive multiple sequence alignment through sequence weighting, position-specific gap penalties and weight matrix choice. Nucleic Acids Res 22, 4673-4680.

Tvrzová, L., Schumann, P., Spröer, C., Sedláček, I., Páčová, Z., Šedo, O., Zdráhal, Z., Steffen, M. \& Lang, E. (2006). Pseudomonas moraviensis sp. nov. and Pseudomonas vranovensis sp. nov., soil bacteria isolated on nitroaromatic compounds, and emended description of Pseudomonas asplenii. Int J Syst Evol Microbiol 56, 2657-2663.

Wu, C., Lu, X., Qin, M., Wang, Y. \& Ruan, J. (1989). Analysis of menaquinone compound in microbial cells by HPLC. Microbiology [English translation of Microbiology (Beijing)] 16, 176-178.

Yumoto, I., Yamazaki, K., Hishinuma, M., Nodasaka, Y., Suemori, A., Nakajima, K., Inoue, N. \& Kawasaki, K. (2001). Pseudomonas alcaliphila sp. nov., a novel facultatively psychrophilic alkaliphile isolated from seawater. Int J Syst Evol Microbiol 51, 349-355. 